\title{
8
}

\section{Observation and Shadowing: Two Methods to Research Values and Values Work in Organisations and Leadership}

\section{Stephen Sirris, Tone Lindheim, and Harald Askeland}

\section{Introduction}

This chapter explains in depth two related methods that can be used for collecting data when researching values: observation and shadowing. Values are both ideational and factual. First, they are conceptions of desirable behaviours, objectives and ideals that are not directly tangible or observable. Second, values are inherent in practices. Through various types of observation, researchers can access the contextual embeddedness of values as accomplished in practices in time and space. However, values need to be interpreted. It is in this context that we focus on values work in the field of organisation and leadership studies and address the following question: How can observation and shadowing be used for data collection when studying values and values work? To answer the question, we review the observation methods used within this discipline and share examples from two research projects that employed shadowing and

\footnotetext{
S. Sirris $(\bowtie) \bullet T$. Lindheim $\bullet$ H. Askeland

VID Specialized University, Oslo, Norway

e-mail: stephen.sirris@vid.no; tone.lindheim@vid.no; harald.askeland@vid.no 
participant observation. We argue that these observational methods are highly relevant for studying values and values work and can be further combined with interviews for the purpose of interpretating values.

\section{Observation Methods in Organisation and Leadership Research}

Studies on values in organisational and managerial practices rely on various methods for data collection (Askeland et al., 2020b). Interviewing, examining documents and studying people in action through observation are three frequently used approaches (Kelly \& Ibrahim, 1991). Observation is often included in research strategies such as case studies and ethnography as it allows for collecting rich data about social practices: what people are doing and how in their natural contexts. Observation is time-consuming, often tiring and stressful, yet incomparably useful when studying situated behaviours and practices like values work. For a considerable period, relatively few observation studies were conducted in the field of organisation and leadership research. Observation, as a method, was developed to a limited extent and usually combined with other methodologies. However, since the 2000s, observation methods have been increasingly used to better capture the dynamics of organisational and managerial practices.

Observation studies were central to research in the early stages of the development of organisation theory. Taylor (1911) developed his principles of efficiency by studying work as it unfolded. Importantly, his approach to observing leadership had a rationalistic and individualistic perspective that focused on the content of management and the factors influencing managers' efficiency. For long, this tradition of observation characterised much of management research. In fact, mainstream managerial research still favours quantitative methods, even as various methods inspired by ethnographic approaches are witnessing a resurgence (Tengblad, 2012). Several theoretical perspectives grew out of close encounters with mundane work and practices within organisations, such as the human relations movement, industrial sociology of the 1950s and theories of group dynamics (Barley \& Kunda, 2001, p. 80). 


\section{Managerial Work Behaviour}

Around 1970, observational studies declined because of the shift towards systems theory and a higher level of abstraction. However, towards the start of the 2000s, many disciplines evidenced a turn towards practice, a trend being echoed within organisation and management studies (Barley $\&$ Kunda, 2001). The enduring tradition of managerial work behaviour (MWB) foregrounds observational data (Arman et al., 2014; McDonald, 2005; Mintzberg, 1970; Tengblad, 2012). The approach has its roots in the diary studies of Carlson (1951), in the work of Stewart in the 1960s (1989) and in Marple's study of sequences and episodes (Marples, 2019). Carlson's study provided insights into the content of managerial work, while Marple' study focused on decision-making sequences. Mintzberg (1970) criticised the use of diaries because the method presupposed that the researcher already knew what managers were doing and sought further knowledge of content in specific categories.

Balancing openness and structure has been, and still is, central to the debate on observation methods. Mintzberg (1970, p. 90) advocated a middle ground, claiming that categories structuring the observation should be defined before conducting the observation. This rationale guided the design of his original study, in which he expanded the richness of data by observing executives. While proposing a methodology to obtain thick descriptions, he addressed what to observe and how: 'I use the label "structured observation" to refer to a methodology which couples the flexibility of open-ended observation with the discipline of seeking' (Mintzberg, 1970, p. 89). Different terminologies have been used to refer to different observation approaches. For example, several studies following Mintzberg adopted the term 'structured observation', while recent studies have downplayed the structured aspect of the approach preferring labels like 'semi-structured' (Noordegraaf \& Stewart, 2000), 'shadowing' (McDonald, 2005) or 'semi-structured shadowing' (Askeland et al., 2015).

Integrating the study of organisational members' and managers' everyday work into organisation theory requires a reorientation towards methods that are high on descriptive accuracy and designs that are suited to 
comparative analysis (Barley \& Kunda, 2001, p. 84). We argue that this requires applying some sort of observational studies and carefully choosing from among the various observational methodologies available. In the initial phase, observational studies often have a wide scope because of their explorative character. The MWB tradition offers semi-structured tools, allowing researchers to delimit the scope, for example, by studying managerial work or values work (Arman et al., 2012; Askeland et al., 2020a; Sirris 2019).

\section{Observation and Shadowing}

As evident in the MWB tradition, observation methods are often emphasised for their assumed relevance to practitioners. We utilise experiences from this tradition as they provide a relevant example of how observation and shadowing can inform the study of values. Just like managerial behaviour, values work is enacted in embedded practices. The following sections illustrate how observation methods facilitate the capturing of organisational and managerial practices, and we begin by examining the differences and similarities between observation and shadowing.

Observation and shadowing are associated approaches of collecting data in situ and in vivo (Zilber, 2020). Compared to methods like interviews or document reviews, observation and shadowing enable access to values work as an ongoing accomplishment. Observation can be placed on a continuum ranging from participant to passive (Fangen, 2010). Ciesielska et al. (2018, p. 34) explained the various modes of observation as follows:

In participant observation, the researcher strives towards an "immersion" in a specific culture, preferably for a longer period of time, in order to acquire an insider understanding of this culture either as a (marginal) member or as a visitor. In non-participant observation, the researcher tries to understand the world, relationships, and interactions in a new way, without prevalent categorizations and evaluations. In indirect observation, the researcher relies on observations done by others (e.g. other researchers) on various types of documentation, recordings, or on auto-observation. 
Shadowing is a form of direct non-participant observation (Czarniawska, 2007). Meunier and Vasquez (2008, p. 168) noted that between shadowing and observation, in the former, the focus of the researcher's attention is the person rather than the location:

However, it differentiates itself from observation in taking the metaphor of the "shadow" literally: The researcher follows a person as his or her shadow, walking in his or her footsteps over a relatively long period of time, throughout his or her different activities, to collect detailed-grained data.

Observational data shares the characteristics of data from other sources of naturalistic inquiry (Lincoln \& Guba, 1985), as the data are socially constructed. Values practices, as they are accomplished, are not selfevident, but require interpretation. Some researchers have advocated for dispelling the traditional distinction between observation and interviewing as both are enacted performances requiring interpretation (Hammersley, 2017). The choice of methods is closely connected to the theoretical perspectives of a study (Zilber, 2020). In values work, studies based on institutional theoretical perspectives, employing an ethnographically sensitive approach or the use of methods like observation and shadowing, are encouraged (Hampel et al., 2017). The following sections describe two forms of observation: participatory and shadowing.

\section{Participant Observation}

Participant observation can be used in various ways to study values in the domain of organisation and leadership. Starting with a research question or an issue of concern, a researcher explores and identifies specific situations and settings in an organisation where the social phenomenon is instantiated. Typical situations could be meetings, sessions of supervision and counselling of employees, small talk over lunch, special events and engagement with external actors. The researcher can also look for different sites to observe values practices: 'the sayings and doings in organizations that articulate and accomplish what is normatively right or wrong, good or bad, for its own sake' (Gehman et al., 2013, p. 85). Sites include 
offices and meeting rooms, hallways and common areas, or virtual sites like phone calls and email correspondence over the internet. Participant observation in values work studies can also take the form of paying attention to the physical environment and artefacts (Stake, 1995). Examples of physical aspects that can be relevant to such a study are the dress code at the site, the size and interiors of the offices and the use of art and symbols in the building. The location of offices and its proximity to or distance from other locations may also be relevant information for a study. Moreover, observation is temporally situated as it happens at a specific time. This makes the celebration of holidays or different anniversaries potentially important information within an organisation.

Theory and findings from other related empirical studies present categories of what to look for during observation. Identifying how values practices are expressed through sayings, doings, relatings and set-ups (Kemmis, 2009) can guide the observer's attention in the research process. The combination of an open inductive question and existing theoretical categories results in an abductive approach to observational data, oscillating between existing theory and data collection.

The researcher plays an active part in participant observation, and in line with other methods of naturalistic inquiry, there are unclear boundaries between the researcher and the researched (Lincoln \& Guba, 1985). This implies that the researcher actively uses his or her own knowledge and experiences to build trust and good relations with the informants to gain access to relevant information. Ideally, the researcher's presence should be as less disturbing or uncomfortable as possible for the participants. Even if the researcher seeks to observe a manager, or employee, without interrupting or influencing the person's work, the researcher's presence is likely to make an impact. See Chap. 13 in this book about researchers' role reflexivity. By participating with the informants in activities like eating lunch together or helping them with practical matters, the researcher engages in what Fangen (2010, p. 74) describes as participating in social interaction but not in context-specific activities. Typically during participant observation, informal interviews take place where the informants share their accounts (Zilber, 2020). Because accounts are context sensitive, those collected during observation are more likely to be valid and correctly interpreted compared to those obtained using 
retrospective interviews exclusively (Hammersley, 2017). See also Chap. 7 in this book about interviews.

\section{Semi-structured Shadowing}

Semi-structured shadowing is a form of observation that involves following a person around as they perform daily work (Askeland et al., 2015; Meunier \& Vásquez, 2008). It is a way of studying 'the work and life of people who move often and quickly from place to place' (Czarniawska, 2014 , p. 92). Shadowing thus implies fixing the observation on a person or an object instead of a location. It involves accompanying a person on the move to different offices and floors in the building, as well as to external locations.

Askeland (2016, p. 112) developed a format to lend structure to shadowing (see Table 8.1). The scheme has columns to indicate the types and content of activities, time, duration and location, the participants involved and who initiated the activity.

To systematise data, the information can be coded, as illustrated in Table 8.2 (Lindheim, 2021, p. 58). This method shares similarities with quantitative observation (Stake, 1995), and the level of structure in these types of observations has been discussed previously (Askeland et al., 2015). The structure provides a clearer focus during observation (Arman et al., 2012, p. 303). At the same time, the coding process allows for a dynamic interpretation, enabling comparison with earlier categories as well as the development of new ones (Sirris, 2016). A critical factor in this type of observation is determining what constitutes an activity. According to Thomas (1998, p. 6), an activity can be 'an episode or series

Table 8.1 Format for semi-structured shadowing

\begin{tabular}{|l|l|l|l|l|l|l|}
\hline Time & Activity & Place & Content & Participants & Initiative & Duration \\
\hline & & & & & & \\
\hline & & & & & & \\
\hline
\end{tabular}


Table 8.2 Coding of semi-structured shadowing

\begin{tabular}{lll}
\hline Pattern of activities & Location of activity & Interaction with \\
\hline Planned meetings & Own office & Subordinates \\
Unplanned meetings & Staff room & Colleagues \\
Professional work & Common areas & Superior \\
Supervision staff & Meeting room & Outsiders \\
Conversations & & \\
Phone & & \\
Office work & & \\
Inspection/tour & & \\
\hline
\end{tabular}

of episodes taking place during one day relating to a subject; for example, preparing a meeting might involve a number of episodes during a day'.

Semi-structured shadowing is a tool to understand the daily practices of the informants and provides an opportunity to compare two or more persons shadowed as part of a study. As such semi-structured shadowing complements the less structured format of participant observation presented above. It is usually followed by an interview in addition to some communication during the shadowing.

To understand what is happening, the researcher will have to ask the informant to explain what he or she is doing, especially when this is not directly observable such as when the person is working on the computer. Such information relaxes the limits imposed by structuring and provides additional overlay data (Askeland et al., 2015; Thomas, 1998). These conversations occasionally turn into informal interviews. The researcher is challenged to maintain a listening attitude without intervening unnecessarily. The shadowed persons can receive a transcript of the shadowing format before the interview, and the transcript and events from the day of shadowing can be discussed in the interview (Askeland et al., 2015).

To sum up, both shadowing and participant observation are often exhausting methods demanding constant attention. Shadowing requires constant notetaking while moving around and following the actor. Czarniawska (2018, p. 69) captures the minor differences between various types of observation as follows: 
Compared to participant observation, shadowing is much easier, because it does not require simultaneous action and observation or skills that the researcher may not have. It also helps in maintaining a distance and a sense of estrangement, whereas participant observers may be tempted to "go native". Shadowing and estrangement do not require that researchers disavow their feelings or negate them; on the contrary, emotions become a critical research instrument.

\section{Researching Values in Practices}

As noted in the introduction, a key issue in observation studies of managerial practices is balancing openness and structure in observation. Structuring observation with pre-defined categories allows for comparison with other studies across time and contexts. Since it is not possible to observe everything, structuring the observations delimits the researcher's gaze (Czarniawska, 2007, cited in Arman et al., 2012, p. 303). The following sections offer examples from two recent research projects that used shadowing. Because researchers who exclusively use pre-defined categories in shadowing risk missing context-sensitive data, here we argue, through these examples, for the dynamic use of structuring when using shadowing in the study of values work. Drawing on our own empirical studies, we demonstrate how this can be done (Askeland et al., 2019; Lindheim, 2021). These studies used the formats presented earlier (Tables 8.1 and 8.2) to record data obtained from shadowing managers. The observation form was complemented by field notes containing thick descriptions of the activities as well as reflections and impressions. Taking notes is a selective activity in itself since every note contains an interpretation of what is important in the observation. The combination of an observation format and fieldnotes not only guides the researcher's inquiry but also instils an openness for unexpected information. As mentioned, it is impossible to observe everything, so the observation is guided by a goal or research question. Researchers benefit immensely from making notes continually to record data that might have an interest, including details and impressions. 


\section{Shadowing Supplemented by Interviews and Document Analysis}

Our first example is a study in which the authors analysed values as a common ground for framing and interpreting organisational practices (Askeland et al., 2019). The researchers collected data through semistructured observation in three faith-based health organisations. These data were supplemented with interviews and analysis of policy documents, which offered a tighter frame for analysing the role of values in preserving the religious identity underpinning the organisations' foundation (Table 8.3).

Since the study focused on organisational self-representations and symbolic practices, the researchers identified four categories of items in which to search for the themes of values and religion: statements from bylaws, statements from strategic plans, CEOs' statements and values and value explications in the policy documents. Next, we mapped CEOs' symbolic practices using Kemmis' (2009) quadruple analysis of set-ups, sayings, doings and relatings. Finally, items were identified for each faithbased health organisation, and the material was coded jointly.

The pre-defined format for observation allowed for field notes to be taken during meetings, activities or long conversations, earlier labelled as overlay data. These notes were especially valuable in deeming how a meeting or activity carried values implications. Sometimes a surprising activity or conversation was tagged as 'follow-up', reminding the observer to bring up the activity during the interview afterwards. This enabled the observed managers to explain the background, intentions or choices made in situ.

Semi-structured shadowing allowed us to follow managers during their work hours and study their various activities. A manager's behaviour or action was deemed a practice when it was guided by intentions and related to other activities in a greater nexus. However, being outsiders, merely observing practices was insufficient; the practices needed to be interpreted. Thus, during the observations and in interviews, the managers were encouraged to comment on the content and purpose of their activities. 
Table 8.3 Connecting methodological triangulation to its contribution for analysis

\begin{tabular}{|c|c|c|c|}
\hline \multicolumn{3}{|c|}{ Sub-methodologies applied } & \multirow{2}{*}{$\begin{array}{l}\text { Contribution to } \\
\text { analysis }\end{array}$} \\
\hline Method & Data gathered & Analytical approach & \\
\hline $\begin{array}{l}\text { Semi-structured } \\
\text { observations/ } \\
\text { shadowing }\end{array}$ & $\begin{array}{l}\text { Five full days of } \\
\text { observation } \\
\text { Seminars for } \\
\text { employees }\end{array}$ & $\begin{array}{l}\text { Categorising } \\
\text { activities } \\
\text { Analysing values } \\
\text { apparent in } \\
\text { interactions } \\
\text { Coding of } \\
\text { articulated values } \\
\text { from policy } \\
\text { documents and } \\
\text { seminars }\end{array}$ & $\begin{array}{l}\text { Behavioural patterns } \\
\text { comparable with } \\
\text { prior studies } \\
\text { Dynamic development } \\
\text { of terms and } \\
\text { categories } \\
\text { Thick and deepened } \\
\text { understanding of } \\
\text { practice }\end{array}$ \\
\hline Interviews & $\begin{array}{l}\text { Three } \\
\text { interviews } \\
\text { with CEOs, } \\
\text { lasting a total } \\
\text { of ten hours } \\
\text { Common core } \\
\text { of interview } \\
\text { guide and } \\
\text { individual } \\
\text { themes }\end{array}$ & $\begin{array}{l}\text { Conceptualisation of } \\
\text { leadership role } \\
\text { Intentionality of } \\
\text { values orientation } \\
\text { and work }\end{array}$ & $\begin{array}{l}\text { Self-conceptualisation } \\
\text { by leaders, } \\
\text { regarding role and } \\
\text { values Work } \\
\text { intention } \\
\text { How values affect } \\
\text { practice } \\
\text { Interaction of the } \\
\text { plurality of logics }\end{array}$ \\
\hline $\begin{array}{l}\text { Document } \\
\text { analysis }\end{array}$ & $\begin{array}{l}\text { Government } \\
\text { white papers } \\
\text { Institutional } \\
\text { policy } \\
\text { documents } \\
\text { and strategic } \\
\text { plans } \\
\text { Minutes of the } \\
\text { board } \\
\text { meetings }\end{array}$ & $\begin{array}{l}\text { Regulative } \\
\text { mechanisms } \\
\text { Sector/field values } \\
\text { and their } \\
\text { translation within } \\
\text { own organisation } \\
\text { Coding narratives of } \\
\text { values and identity }\end{array}$ & $\begin{array}{l}\text { Ramifications of } \\
\text { field-level policies } \\
\text { Relating field-level } \\
\text { and organisational } \\
\text { values } \\
\text { Conveying of values } \\
\text { and identity as } \\
\text { intentional values } \\
\text { work }\end{array}$ \\
\hline
\end{tabular}

The interviews covered issues such as the managers' backgrounds, their understanding of their role and main responsibilities, their identification with the institution's values base and their patterns of interactions. To broaden the understanding of practices within the organisations, the national welfare policy documents and institutional documents on strategy, identity and values were analysed. These data revealed that some of the institutions had chosen values that were congruent with those 
articulated in government white papers, laws or policies. Yet, a closer analysis showed how they were translated for internal purposes and given ideological interpretations or were fitted into the larger identity narrative of the organisation. Lastly, the study included a review of earlier research reports from first-hand studies conducted in the same organisations.

To sum up, the observational data and transcribed interviews served as the empirical basis for analysis. First, we performed a preliminary analysis by reading the fieldnotes from the observations, the transcribed interviews and the policy documents. In the second phase, we analysed thematically how values appeared in the material and how the managers were involved in articulating and embodying the values. The observational data were coded and analysed according to the values involved in a given situation and how they were exercised. Given that such interpretations are subject to judgement and uncertainty, we prioritised examples in which values were directly articulated. A key contribution of the study was the description of the role of values as a common ground for framing and interpreting organisational and professional practices. Further, the study identified the possibilities and limitations of values in translating and expressing religion.

\section{Observation and Shadowing}

Our second example is a case study of cultural diversity and inclusion in three nursing homes (Lindheim, 2020a, 2020b). The study used participant observation, shadowing and interviews to collect data. Combining the two forms of observations, as opposed to only shadowing managers, allowed access to a wider range of organisational practices. The following paragraphs illustrate how values concerning cultural diversity and inclusion surfaced in organisational practices, and how observation and shadowing elicited information that would otherwise not have been accessed.

At a management meeting in one of the nursing homes, the CEO referred to the organisational values to justify why the unit should offer language training to refugees receive refugees: 
Many refugees arrived in Norway a year ago. They need to settle down here and acquire employment. We have committed to assume responsibility in this together with the city district. We will facilitate language practice in all of Hope and Justice's [the owner of the nursing home] entities. Specifically, we now talk about two persons from Syria - a man and a woman. They are doing language training, and the plan is that they will spend three days a week in the language course and two days a week in language practice, for three months, in order to learn Norwegian. They are not going to do regular healthcare tasks, but they should practice Norwegian with residents and employees. Primarily employees. We need a unit that can receive them (Excerpt from field notes).

Through his intervention in the management meeting, the CEO articulated and related values to organisational practices, engaging in what could be termed institutional leadership (Askeland, 2020). Observation in situ and in vivo provides access to how this plays out in the everyday life of the organisation.

The researcher shadowed one of the unit managers in a nursing home when she interviewed a candidate for a vacant night-shift position together with another unit manager. The candidate was from Poland, and while walking out of the interview, one of the unit managers said to the other: 'She wasn't very Polish, I mean, with lots of make-up and long nails, and so on'. The quote is an example of how observation can provide access to actors' engagement with values-related practices as they are accomplished. Such practices would likely have been presented differently in a formal interview were interviewees, to a greater extent, present themselves in a more favourable light.

Observing employees in the nursing homes elicited a topic that had not been on the researcher's radar prior to the field work-caring for residents from a cultural and religious minority background. Even though the vast majority of residents in the nursing homes were of Norwegian descent, an increasing number of residents belonged to minority backgrounds. One of the units had a Muslim resident from South Asia with severe dementia. The man was observed to be frequently restless and upset. Often, he would sit in the common living room or the dining area and pray quite loudly. The unit manager told the researcher how the 
family members of other residents from the majority background were quite upset about the situation and had demanded that the man be moved to another nursing home to prevent him from disturbing their relatives. By shadowing the unit manager, the researcher observed that the manager discussed the issue with other employees, insisting that the nursing home was the Muslim man's home, too. The example demonstrated the unit manager's values work: defending the man's right to be in the nursing home. It is also an example of how observation may yield topics that would otherwise not be considered. A key contribution of the study was the finding that observation elicits the dynamics between espoused and enacted values, which may support or counter each other. The study furthered showed how values come into play and are made relevant in everyday organisational practices.

\section{Contributions and Implications of Observational Methods}

How do observation and shadowing as methods for data collection contribute to the study of values and values work? Social phenomena like values work emerge out of practices accomplished in space and time (Nicolini \& Monteiro, 2017); thus, the study of values work requires methods, like observation and shadowing, that attend to what is empirically observable (Janssens \& Steyaert, 2019). A benefit of observation as a method is the access it provides to what people say and do in a context that is not structured by the researcher. Another advantage is that through prolonged or intense exposure to the phenomenon under study, the researcher builds rapport and trust with the participants. This, in turn, can ensure that the perspectives of multiple actors are collected and understood (Lincoln \& Guba, 1985). Observing values practices as they are accomplished reduces the potential for social desirability responses. At the same time, values are ambiguous in their very nature (Sirris, 2020), not readily observable but manifest in the practice itself or in how the actors frame and interpret practices. For such reasons, a combination of methods is particularly suited when studying values work. 
Despite the advantages discussed above, observation and shadowing are not without challenges. Stewart (1989) identified the problem of understanding what is going on when shadowing managers. Observational data may inadvertently lead researchers to judge and evaluate the content instead of accurately describing what is going on from the actors' viewpoint. Our proposal introduces a semi-structured approach to nonparticipant observation (Ciesielska et al., 2018), thus delimiting the gaze (Arman et al., 2012) and tapping into dimensions and categorisations grounded in prior research. This, thus, seems to necessitate some level of precision in the research questions being informed by existing research. Supplementing observational data with interviews expands the researcher's understanding by including the actors' interpretation of what happened. An action is in itself ambiguous and open to manifold interpretations. The interview thus serves as a supplement or even a necessary corrective.

Essentially, shadowing and participant observation are observational approaches that complement each other. In the examples presented above, managers play a key role, but values work is not limited to managers. Values are constituted, maintained and changed in dialectical interactions of actors and coalitions. Broadening the scope of observation beyond the shadowing of managers allows the researcher to study other actors' reactions and responses to managers' values work. The key advantage of shadowing is its mobility (Czarniawska, 2007, p. 56), compared to the stationary nature of observation. The main difference between the two forms is the foregrounding of the actor in shadowing, whereas the participatory approach favours the location as the focus of observation. While shadowing is a form of non-participatory observation, participatory means an explicit engagement in interactions and sometimes involvement in actions. These two approaches offer different perspectives on how values work is performed, each giving prominence to the individual actor-usually a manager — or to the given practice entailed in the social interaction. The research question and aim of the study should guide the choice of approach, as illustrated in the two studies presented above. 


\section{Concluding Remarks}

This chapter has summarised the multiple possibilities that participant observation and shadowing offer in their own right and in combination with other methods. Observation can be used to register activities and present data statistically. Yet, it can also be ethnographically based and provide thick descriptions. We recommend the use of observation along with interviews as a supplementary method. Both shadowing and participant observation have the potential to illuminate the core dimensions of practices like values work. Their complexity is inherent, as they are context sensitive, situated in time and space and open to interpretations of the actors.

\section{References}

Arman, R., Liff, R., \& Wikström, E. (2014). The hierarchization of competing logics in psychiatric care in Sweden. Scandinavian Journal of Management, 30(3), 282-291.

Arman, R., Vie, O. E., \& Åsvoll, H. (2012). Refining shadowing methods for studying managerial work. In S. Tengblad (Ed.), The work of managers. Towards a practice theory and management (pp. 301-317). Oxford University Press.

Askeland, H. (2016). Hverdagsledelse: Diakoni, verdier og ledelse i praksis [Everyday management: Diaconia, values and management in practice]. Doctoral dissertation, VID Specialized University / The Norwegian School of Theology, Oslo. http://www.mf.no/sites/mf/files/users/askeland_materie.pdf Askeland, H. (2020). Institutional leadership: Maintaining and developing the 'Good' organisation. In H. Askeland, G. Espedal, B. J. Løvaas, \& S. Sirris (Eds.), Understanding values work. Institutional perspectives in organizations and leadership (pp. 139-158). Palgrave. https://doi.org/10.1007/978-3-030-37748-9_8 Askeland, H., Blomander, C., \& Aasen, A. (2015). Jakten på ledelse i praksis. Semistrukturert følge-observasjon som metode innenfor ledelsesforskning. Nordiske Organisasjonsstudier, 17(1), 3-30.

Askeland, H., Espedal, G., Løvaas, B. J., \& Sirris, S. (2020a). Understanding values work in organisations and Leadership. In H. Askeland, G. Espedal, B. J. Løvaas, \& S. Sirris (Eds.), Understanding values work (pp. 1-12). Palgrave. https://doi.org/10.1007/978-3-030-37748-9_1 
Askeland, H., Espedal, G., Løvaas, B. J., \& Sirris, S. (2020b). Understanding values work in organisations and Leadership. In Understanding values work (pp. 1-12). Springer.

Askeland, H., Espedal, G., \& Sirris, S. (2019). Values as vessels of religion? The role of values in everyday work at faith-based organizations. Diaconia, 10(1), 27-49.

Barley, S. R., \& Kunda, G. (2001). Bringing work back in. Organization Science, 12(1), 76-95.

Carlson, S. (1951). Executive behaviour: A study of the work load and the working methods of managing directors. Smartbergs.

Ciesielska, M., Boström, K. W., \& Öhlander, M. (2018). Observation methods. In M. Ciesielska \& D. Jemielniak (Eds.), Qualitative methodologies in organization studies (pp. 33-52). Springer.

Czarniawska, B. (2007). Shadowing and other techniques for doing fieldwork in modern societies. Liber Universitetsforlaget.

Czarniawska, B. (2014). Why I think shadowing is the best field technique in management and organization studies. Qualitative Research in Organizations and Management, 9(1), 90-93. https://doi.org/10.1108/ QROM-02-2014-1198

Czarniawska, B. (2018). Fieldwork techniques for our times: Shadowing. In M. Ciesielska \& D. Jemielniak (Eds.), Qualitative methodologies in organization studies (pp. 53-74). Palgrave Macmillan.

Fangen, K. (2010). Deltagende observasjon [Participant observation]. Fagbokforlaget.

Gehman, J., Trevino, L. K., \& Garud, R. (2013). Values work: A process study of the emergence and performance of organizational values practices. Academy of Management Journal, 56(1), 84-112.

Hammersley, M. (2017). What is ethnography? Can it survive? Should it? Ethnography and Education, 13(1), 1-17. https://doi.org/10.1080/1745782 3.2017.1298458

Hampel, C., Lawrence, T. B., \& Tracey, P. (2017). Institutional work. Taking stock and making it matter. In R. Greenwood, C. Oliver, T. B. Lawrence, \& R. E. Meyer (Eds.), The Sage handbook of organizational institutionalism (pp. 558-590). SAGE.

Janssens, M., \& Steyaert, C. (2019). A practice-based theory of diversity: Re-specifying (in)equality in organizations. Academy of Management Review, 44(3), 518-537. https://doi.org/10.5465/amr.2017.0062

Kelly, J., \& Ibrahim, A. B. (1991). Executive behavior: Its facts, fictions and paradigms. Business Horizons, 34(2), 27-36. 
Kemmis, S. (2009). Understanding professional practice: A synoptic framework. In B. Green (Ed.), Understanding and researching professional practice (pp. 19-38). Brill Sense.

Lincoln, Y. S., \& Guba, E. G. (1985). Naturalistic inquiry (SAGE ed.).

Lindheim, T. (2020a). Developing religious literacy through conversational spaces for religion in the workplace. Nordic Journal of Religion and Society, 33(1), 16-29. https://doi.org/10.18261/issn.1890-7008-2020-01-02

Lindheim, T. (2020b). 'Good leaders do the dirty work': Implicit leadership theory at the multicultural workplace. In H. Askeland, G. Espedal, B. J. Løvaas, \& S. Sirris (Eds.), Understanding values work. Institutional perspectives in organizations and leadership. Palgrave. https://library.oapen.org/bitstream/ handle/20.500.12657/37706/2020_Book_UnderstandingValuesWork. pdf?sequence=1\#page=105. https://doi.org/10.1007/978-3-030-37748-9_6

Lindheim, T. (2021). Opening and closing doors - Managing at the multicultural workplace. A case study of cultural diversity and inclusion in nursing homes. Doctoral dissertation, VID Specialized University, Oslo.

Marples, D. (2019). Studies of managers - A fresh start? In Managerial work (pp. 191-208). Routledge.

McDonald, S. (2005). Studying actions in context: A qualitative shadowing method for organizational research. Qualitative Research, 5(4), 455-473.

Meunier, D., \& Vásquez, C. (2008). On shadowing the hybrid character of actions: A communicational approach. Communication Methods and Measures, 2(3), 167-192.

Mintzberg, H. (1970). Structured observation as a method to study managerial work. The Journal of Management Studies, 7(1), 87-104.

Nicolini, D., \& Monteiro, P. (2017). The practice approach: For a praxeology of organisational and management studies. In A. Langley \& H. Tsoukas (Eds.), The SAGE handbook of process organization studies (pp. 110-126). SAGE.

Noordegraaf, M., \& Stewart, R. (2000). Managerial behaviour research in private and public sectors: Distinctiveness, disputes and directions. Journal of Management Studies, 37(3), 427-443.

Sirris, S. (2016). Arbeidsdager mellom profesjon, ledelse og organisasjon. Soknepresters tidsbruk og aktivitetsmønstre. [Work days between profession, management and organisation. Senior pastors' time-use and patterns of activity]. Teologisk Tidsskrift, 4(1), 60-88.

Sirris, S. (2019). Managers negotiating identities. Hybridizing professionalism in faith-based health organizations and religious organizations. (PhDdissertation). VID Specialized University. 
Sirris, S. (2020). Values as fixed and fluid: Negotiating the elasticity of core values. In H. Askeland, G. Espedal, B. J. Løvaas, \& S. Sirris (Eds.), Understanding values work (pp. 201-221). Palgrave Macmillan.

Stake, R. E. (1995). The art of case study research. SAGE.

Stewart, R. (1989). Studies of managerial jobs and behaviour: The ways forward. Journal of Management Studies, 26(1), 1-10.

Taylor, F. W. (1911). Scientific management. Happer \& Bros. Publishers.

Tengblad, S. (2012). The work of managers: Towards a practice theory of management. Oxford University Press.

Thomas, A. R. (1998). Knowing principals through observations: What has the method taught us? Paper presented at the Annual Conference of the Australian Associations for Research in Education, Adelaide.

Zilber, T. B. (2020). The methodology/theory interface: Ethnography and the microfoundations of institutions. Organization Theory, 1(2), 1-27. https:// doi.org/10.1177/2631787720919439

Open Access This chapter is licensed under the terms of the Creative Commons Attribution 4.0 International License (http://creativecommons.org/licenses/ by/4.0/), which permits use, sharing, adaptation, distribution and reproduction in any medium or format, as long as you give appropriate credit to the original author(s) and the source, provide a link to the Creative Commons licence and indicate if changes were made.

The images or other third party material in this chapter are included in the chapter's Creative Commons licence, unless indicated otherwise in a credit line to the material. If material is not included in the chapter's Creative Commons licence and your intended use is not permitted by statutory regulation or exceeds the permitted use, you will need to obtain permission directly from the copyright holder.

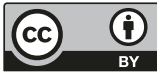

